\title{
FAKTOR-FAKTOR YANG MEMPENGARUHI CASH HOLDINGS PERUSAHAAN DI BURSA EFEK INDONESIA
}

\author{
Suherman \\ Fakultas Ekonomi Universitas Negeri Jakarta \\ suherman@unj.ac.id
}

\begin{abstract}
The purpose of this study is to examine determinants of cash holdings of nonfinancial firms listed on Indonesia Stock Exchange between 2012 and 2015. Sample of this research covers 328 firms (1312 observations). This research employs fixed effect model. The results show that net working capital and sales growth have positive effects on cash holding, while firm size has negative effect. Cash flow, cash flow variability, cash conversion cycle, liquidity, leverage do not affect the cash holdings.
\end{abstract}

Keywords: cash holding, cash flow, cash flow variability, cash conversion cycle, liquidity, leverage, net working capital, sales growth, firm size

\begin{abstract}
Abstrak: Tujuan dari penelitian ini adalah untuk menguji faktor-faktor yang berpengaruh terhadap cash holdings pada perusahaan non finansial yang terdaftar di Bursa Efek Indonesia dari tahun 2012 sampai 2015. Sampel penelitian ini menggunakan 328 perusahaan (1312 observasi). Penelitian ini menggunakan fixed effect model. Hasil penelitian mengungkapkan bahwa net working capital dan sales growth berpengaruh positif signifikan terhadap cash holding, sedangkan firm size memiliki pengaruh negatif signifikan. Sementara cash flow, cash flow variability, cash conversion cycle, liquidity, dan leverage tidak berpengaruh terhadap cash holdings
\end{abstract}

Kata kunci: cash holding, cash flow, cash flow variability, cash conversion cycle, liquidity, leverage, net working capital, sales growth, firm size

\section{PENDAHULUAN}

Ketersediaan kas adalah hal yang sangat penting dalam suatu perusahaan terutama dalam kegiatan transaksional dan operasional perusahaan. Memegang kas dalam jumlah banyak dapat memberikan berbagai keuntungan bagi perusahaan dimana salah satunya adalah untuk pembiayaan hal-hal yang tidak terduga (unexpected expenses). Namun, memegang kas berlebihan juga memiliki sisi negatif, yaitu hilangnya kesempatan perusahaan memperoleh laba karena kas yang hanya disimpan tersebut tidak akan memberikan pendapatan. Oleh karena itu, masalah yang sering dihadapi oleh seorang manajer keuangan adalah menjalankan kegiatan operasional perusahaan dengan tetap menjaga keseimbangan jumlah kas perusahaan. Dengan semakin pentingnya mengatur keseimbangan jumlah kas perusahaan, maka semakin banyak perhatian dari berbagai pihak seperti para manajer dan investor terhadap kepemilikan kas perusahaan (Al-Najjar, 2013; Jamil et al, 2016).

Bagi manajer keuangan, menentukan tingkat kas perusahaan adalah suatu keputusan penting yang harus diambil demi kelangsungan kinerja keuangan perusahaan. Saat perusahaan memperoleh pemasukkan kas, maka manajer harus membuat keputusan apakah kas tersebut akan dipakai untuk pembagian dividen kepada para pemegang saham, melakukan kegiatan investasi, melakukan pembelian saham, atau menyimpan kas tersebut 
untuk keperluan lain di masa mendatang. Terdapat banyak alasan yang mendasari perusahaan meningkatkan jumlah kasnya. Salah satunya adalah motif transaksi yang menjelaskan bahwa perusahaan memegang aset likuid dengan tujuan menghemat biaya konversi ke bentuk kas, sehingga bila ada kebutuhan yang darurat, perusahaan dapat segera memenuhinya (Jinkar, 2013).

Pada umumnya suatu perusahaan menginginkan tersedianya kas untuk memenuhi kebutuhan akan proyek-proyek investasi yang menguntungkan di masa mendatang. Melalui alasan ini, maka dapat dikatakan bahwa memiliki aset dalam bentuk likuid akan lebih menguntungan untuk perusahaan yang memiliki peluang investasi yang lebih besar daripada perusahaan yang memiliki ketidakpastian akan peluang investasi dikarenakan masalah keuangan yang dihadapinya (William dan Fauzi, 2013).

Beberapa penelitian yang mengkaji faktor yang mempengaruhi besarnya cash holding perusahaan di Indonesia telah dilakukan. Di antaranya adalah Marfuah dan Zulhilmi (2015) menguji pengaruh growth opportunity, net working capital, cash conversion cycle, dan leverage terhadap cash holding perusahaan. Jinkar (2013) menguji faktor-faktor penentu kebijakan cash holding di perusahaan manufaktur yang terdaftar di BEI. Dari penelitian tersebut ditemukan bahwa variabel growth opportunity, leverage, dan net working capital berpengaruh terhadap cash holdings, sedangkan size, cash flow dan capital expenditure tidak berpengaruh terhadap cash holding. Penelitian mengenai faktorfaktor yang mempengaruhi corporate cash holding di Indonesia menggunakan sampel dan observasi sedikit. Weidemann (2016) mengungkapkan bahwa hasil penelitian determinan cash holdings di Amerika dan Eropa berbeda dengan temuan determinan cash holdings di Asia. Bahkan, di negara-negara Asia pun determinan cash holding berbeda (Weidemann, 2016; Chen et al., 2015). Berbeda dengan penelitian sebelumnya di Indonesia, penelitian ini menggunakan sampel dan observasi yang relatif banyak (328 perusahaan sampel dengan 1312 observasi). Penelitian ini juga memberi tambahan bukti tentang faktor-faktor apa saja yang berpengaruh terhadap cash holding perusahaan, khususnya di Indonesia.

Penelitian ini memberikan kontribusi berupa bukti empiris mengenai faktor-faktor yang berpengaruh terhadap cash holding perusahaan. Penelitian ini dapat dijadikan bahan pertimbangan bagi perusahaan untuk membuat keputusan berkaitan dengan penentuan tingkat cash holding perusahaan. Tujuan dari penelitian ini adalah untuk menguji faktorfaktor yang berpengaruh terhadap corporate cash holding pada perusahaan non finansial yang terdaftar di Bursa Efek Indonesia (BEI) periode 2012-2015.

Hasil dari penelitian ini mengungkapkan bahwa variabel net working capital dan sales growth berpengaruh positif signifikan terhadap corporate cash holding sedangkan variabel firm size berpengaruh negatif signifikan. Untuk variabel lain yaitu cash flow, cash flow variability, cash conversion cycle, liquidity, dan leverage tidak berpengaruh signifikan terhadap corporate cash holding.

Berikutnya ditulis mengenai kajian literatur dan hipotesis pada bagian dua, metodologi penelitian pada bagian tiga, hasil penelitian dan pembahasan pada bagian empat, serta kesimpulan dan saran pada bagian lima.

\section{KAJIAN TEORI}

Teori Free Cash Flow. Hipotesis Arus Kas Bebas (Free Cash Flow) menyatakan bahwa cash holdings merupakan akibat dari perilaku manajer yang bersifat bebas (discretionary) (Jensen, 1986). Manajer yang tidak diawasi dengan baik akan bertindak untuk 
kepentingannya sendiri. Manajer mengadakan kas dari sumber internal karena hal ini tidak meningkatkan disiplin eksternal dan dapat dengan mudah dipakai untuk kepentingan manajer. Hipotesis Free Cash Flow mengasumsikan bahwa diskresi manajerial akhirnya akan menarik disiplin eksternal dalam bentuk pengambilalihan paksa. Faleye (2004) mengungkapkan perlawanan terhadap pengambilalihan paksa sebagai motif yang memperluas hipotesis FCF dengan cara bagaimana manajer menggunakan cash holdings untuk menjaga perusahaan dari ancaman pengambilalihan. Manajer mengantisipasi ancaman ini dan merespon ancaman tersebut dengan menimbun lebih banyak cash untuk mempermudah aplikasi provisi pengambilalihan, seperti membeli kembali saham perusahaan (Faleye, 2004).

Teori Trade-Off. Teori Trade-Off menyatakan bahwa perusahaan menetapkan tingkat kas optimal mereka dengan membandingkan manfaat marginal dengan biaya marginal dari memegang aset likuid (Al-Najjar dan Belghitar, 2011; Martinez-Sola et al. 2013). Pendapat yang hampir sama di kemukakan oleh Dittmar, Mahrt-Smith, dan Servaes (2003), mereka berpendapat bahwa dalam teori trade-off perusahaan memaksimalkan nilai-nilai mereka dengan mempertimbangkan biaya marjinal dan manfaat marjinal dari memegang kas. Dengan asumsi bahwa manajer bertujuan untuk memaksimalkan kekayaan pemegang saham, memegang kas akan menghasilkan "cost-of-carry". Biaya ini berkaitan dengan perbedaan antara pendapatan dari memegang kas dan kepentingan bahwa perusahaan akan membayar untuk mendanai kas tambahan.

Teori Pecking Order. Teori pecking order didasarkan pada penelitian Myers dan Majluf (1984). Teori ini menunjukkan penjelasan untuk perilaku pembiayaan perusahaan sehingga perusahaan memiliki kecenderungan untuk mengutamakan sumber dana internal daripada dana eksternal. Teori ini menunjukkan bahwa perusahaan tidak memiliki tingkat target kas, tetapi kas digunakan sebagai penyangga antara laba ditahan dan kebutuhan investasi. Dengan demikian, motif untuk memegang kas adalah untuk menghindari pembiayaan eksternal. Akibatnya, ketika laba ditahan tidak memadai untuk membiayai investasi baru, perusahaan akan menggunakan kepemilikan kas kemudian mengeluarkan utang baru dan akhirnya ketika mereka memiliki kemampuan pelunasan hutang, mereka akan menerbitkan surat berharga (Kariuki et al., 2015).

Cash Holdings. Kas adalah pembayaran yang siap dan bebas digunakan untuk kegiatan perusahaan. Kas dapat berupa uang tunai atau deposito di bank untuk segera dan diterima sebagai alat pembayaran sesuai dengan jumlahnya. Menurut Ogundipe et al., (2012) cash holding didefinisikan sebagai kas yang ada di perusahaan atau tersedia untuk investasi pada aset fisik dan untuk dibagikan kepada para investor. Karena itu cash holding dipandang sebagai kas dan ekuivalen kas yang dapat dengan mudah diubah menjadi uang tunai. Jumlah kepemilikan kas yang cukup mengindikasikan kelikuiditasan yang baik dari suatu perusahaan. Setiap perusahaan akan sebisa mungkin berusaha untuk menyediakan kas dalam jumlah yang ideal yang artinya tidak terlalu banyak ataupun tidak terlalu sedikit. Jika kas yang dimiliki perusahaan terlalu banyak akan mengakibatkan turunnya efisiensi karena tertanamnya dana berupa kas yang sebenarnya tidak produktif dan dapat mengganggu likuiditas perusahaan, sedangkan jika kas yang dimiliki perusahaan terlalu sedikit juga akan mengganggu likuiditas perusahaan karena dana yang dimiliki dalam kegiatan operasional dan untuk pembayaran utang jangka pendek juga kurang. 
Motif Cash Holdings. Menurut Keynes (Marfuah dan Zulhilmi, 2015) terdapat beberapa motif perusahaan memegang kas, antara lain:

a. Transaction motive. Menurut teori ini perusahaan menahan kas untuk membiayai berbagai transaksi perusahaan. Apabila perusahaan mudah mendapatkan dana dari pasar modal, cash holding tidak diperlukan namun jika tidak, maka perusahaan perlu cash holding untuk membiayai berbagai transaksi. Apabila terdapat asimetri informasi dan agency cost of debt yang tinggi akan menjadikan sumber pendanaan eksternal juga akan semakin tinggi yang menyebabkan jumlah cash holding juga menjadi semakin besar.

b. Precaution motive. Menurut teori ini perusahaan memiliki cash holding dengan tujuan untuk mengantisipasi peristiwa yang tidak terduga dari aspek pembiayaan, terutama pada negara dengan perekonomian yang tidak stabil. Pasar modal akan terpengaruh oleh keadaan ekonomi yang bersifat makro seperti perubahan nilai tukar yang dapat berpengaruh terhadap nilai hutang perusahaan. Hal ini menyebabkan perusahaan memerlukan cash holding untuk mengantisipasi berbagai kemungkinan buruk perekonomian.

c. Speculation motive. Teori ini menyatakan bahwa perusahaan akan menggunakan kas untuk berspekulasi mengamati berbagai kesempatan bisnis baru yang dianggap menguntungkan. Perusahaan yang sedang berkembang dapat melakukan akuisisi perusahaan lain sehingga memerlukan kas dalam jumlah besar.

d. Arbitrage motive. Teori ini menyatakan bahwa perusahaan menahan kas untuk memperoleh keuntungan dari adanya berbagai perbedaan kebijakan antar negara. Perusahaan dapat mengambil dana dari pasar modal asing dengan bunga yang lebih rendah kemudian melalui mekanisme perdagangan dana tersebut ditanamkan pada pasar modal domestik yang memiliki tingkat bunga yang lebih tinggi.

Hipotesis. Cash flow atau arus kas adalah suatu laporan yang menyajikan informasi tentang arus kas masuk dan arus kas keluar suatu perusahaan pada periode waktu tertentu. Basheer (2014) menemukan hubungan positif dan signifikan antara cash flow dan cash holding. Hubungan positif tersebut konsisten dengan prediksi dari teori pecking order yang menyatakan bahwa perusahaan denga arus kas yang tinggi lebih memilih untuk menyimpan jumlah kas secara signifikan. Uyar dan Kuzey (2014) menemukan hubungan yang sama. Kim et al. (2011) mengatakan terdapat hubungan negatif antara cash flow dan cash holding karena cash flow dari kegiatan operasi mengurangi kebutuhan untuk memegang cadangan kas. Teori trade-off dari cash flow menyatakan bahwa cash flow berperan sebagai sumber siap pakai dari likuiditas contohnya mereka dapat digunakan sebagai pengganti kas (Kim et al.2011) dan terdapat hubungan negatif antara cash flow dan cash holdings. Oleh karena itu, perusahaan dengan cash flow yang tinggi cenderung akan memegang lebih sedikit kas. Oleh karena itu, hipotesis penelitian ini dirumuskan sebagai berikut:

H1: Cash flow berpengaruh negatif terhadap cash holding.

Variabilitas adalah rasio standar deviasi arus kas terhadap total aset rata-rata (Ozkan dan Ozkan, 2004). Basheer (2014) menemukan hubungan negatif antara variabilitas arus kas dengan cash holding. Sementara itu, Opler et al. (1999), Ozkan dan Ozkan (2004), Ferreira dan Vilela (2004), dan Bigelli dan Sanchez-Vidal (2012) menemukan hubungan positif antara variabilitas arus kas dan cash holding. Alasan dari hubungan positif ini adalah perusahaan dengan arus kas yang lebih stabil dan aset yang kurang likuid memegang lebih banyak kas untuk memenuhi kebutuhan transaksional dan pencegahan. Variabilitas arus kas yang tinggi juga beresiko bagi perusahaan, oleh karena itu 
perusahaan memutuskan untuk memegang lebih banyak kas untuk motif pencegahan. Berdasarkan uraian tersebut, maka dirumuskan hipotesis penelitian sebagai berikut:

H2: Cash flow variability berpengaruh positif terhadap cash holding.

Siklus konversi kas (Cash Conversion Cycle-CCC) didefinisikan sebagai manajemen harian dari aset dan kewajiban yang dipraktekkan dan berperan penting dalam kesuksesan suatu perusahaan. William dan Fauzi (2013) menyatakan bahwa perusahaan baik sektor publik maupun swasta akan tidak begitu memerlukan kas jika mereka memiliki siklus konversi kas (CCC) yang singkat. Menurut Anjum dan Malik (2013), terdapat hubungan negatif antara siklus konversi kas dengan cash holding sehingga peningkatan siklus menyebabkan saldo kas yang lebih rendah dan oleh karena itu, siklus perusahaan yang lebih besar cenderung memiliki saldo kas yang lebih rendah daripada siklus perusahaan yang lebih kecil dengan saldokas yang lebih tinggi. Hubungan antara cash conversion cycle dan cash holdings lebih jelas ditunjukkan oleh penelitian yang dilakukan oleh Bigelli dan Sanchez-Vidal (2012) yang mengungkapkan cash conversion cycles berpengaruh terhadap penentuan tingkat penahanan kas. Cash conversion cycle diperkirakan memiliki hubungan negatif dengan cash holding. Hal ini karena pada saat cash conversion cycle tinggi maka penerimaan kas akan tertunda sehingga kas yang dipegang perusahaan lebih sedikit (Al-Shubiri dan Aburumman, 2013). Oleh karena itu, hipotesis penelitian ini dirumuskan sebagai berikut:

H3: Cash conversion cycle berpengaruh negatif terhadap cash holding.

Likuiditas adalah kemampuan perusahaan dalam memenuhi kewajiban jangka pendeknya. Likuiditas dapat diukur dengan rasio likuiditas. Dalam mengukur rasio likuiditas terdapat dua cara, yaitu dengan menggunakan rasio lancar (current ratio) dan rasio cepat (quick ratio). Dalam penelitian ini, rasio yang digunakan untuk mengukur likuiditas adalah rasio lancar (current ratio). Opler et al (1999), Ferreira dan Vilela (2004) dan Ozkan dan Ozkan (2004) mengungkapkan hubungan negatif antara likuiditas dan cash holding dengan argumen bahwa perusahaan dapat memenuhi kebutuhan pencegahan dan transaksionalnya dengan aset likuid dan dapat digunakan sebagai pengganti kas. Semakin besar likuiditas perusahaan maka semakin besar aset likuid yang dapat digunakan sebagai pengganti kas sehingga perusahaan lebih sedikit memegang kas karena sudah digantikan oleh aset likuid tersebut. Basheer (2014) dan Uyar dan Kuzey (2014) juga menemukan hubungan negatif dan signifikan antara likuiditas dan cash holding. Berdasarkan uraian tersebut, maka dirumuskan hipotesis penelitian sebagai berikut:

H4: Liquidity berpengaruh negatif terhadap cash holding.

Ali et al (2016) dan Basheer (2014) menemukan hubungan negatif antara leverage dan cash holding. Marfuah dan Zulhilmi (2015) juga menemukan hubungan yang sama. Hal ini menunjukkan bahwa leverage yang besar menunjukkan kekuatan perusahaan menuju akses sumber pembiayaan perusahaan. Perusahaan yang memiliki dukungan hutang yang kuat dalam sumber pendanaannya, tidak perlu memegang kas dalam jumlah besar karena hutang dapat menjadi substitusi bagi kas perusahaan untuk membiayai berbagai aktivitas perusahaan. Perusahaan dengan tingkat utang yang tinggi kurang mampu menyimpan kas karena peran pemantauan yang lebih tinggi dari lembaga keuangan (Kariuki, 2015). Oleh karena itu, dirumuskan hipotesis penelitian sebagai berikut:

H5: Leverage berpengaruh negatif terhadap cash holding.

Jamil et al (2016) dan Jinkar (2013) menemukan hubungan positif antara net working capital (NWC) dan cash holding. Kafayat et al. (2014) juga menemukan hubungan positif 
antara NWC dan cash holding yang menunjukkan bahwa semakin besar kebutuhan perusahaan untuk NWC maka semakin banyak mereka menyimpan kas. Sebaliknya, Ali et al (2016) dan Anjum dan Malik (2013) menyatakan terdapat hubungan terbalik ada antara kas dan NWC. Hal ini karena NWC terutama terdiri dari aset cair pengganti kas. Jadi pada periode waktu tertentu suatu perusahaan hanya dapat mempertahankan kas atau aset likuid dengan tingkat paling tinggi. Peneliti sebelumnya seperti Bates et al. (2009), Ferreira dan Vilela (2003) dan Opler et al. (1999) juga meramalkan adanya hubungan yang sama. Sama halnya dengan likuiditas, jika net working capital tinggi maka perusahaan memiliki lebih banyak aset likuid karena NWC sebagian besar terdiri dari aset likuid pengganti kas. Oleh karena itu, perusahaan memutuskan memegang kas lebih sedikit. Hipotesis yang dirumuskan adalah sebagai berikut:

H6: Net working capital berpengaruh negatif terhadap cash holding.

Sales growth adalah peningkatan penjualan selama periode waktu tertentu, hal ini seringkali terjadi pada perusahaan tetapi belum tentu terjadi setiap tahunnya. Rasio pertumbuhan penjualan adalah rasio yang mengukur pertumbuhan penjualan suatu perusahaan dan dapat dihitung dengan cara mengukur perbedaan atau selisih dari nilai penjualan pada suatu periode yang ditentukan. Perusahaan dengan pertumbuhan penjualan yang tinggi, arus kas yang lebih beresiko, dan perusahaan dengan biaya riset dan pembangunan yang positif menyimpan lebih banyak rasio kas dari total aset (Akguc dan Choi, 2013). Uyar dan Kuzey (2014) juga menemukan hasil yang sama. Motif pencegahan memprediksi bahwa perusahaan dengan peluang pertumbuhan yang lebih baik akan memegang lebih banyak kas (Bates et al., 2009). Ketika pertumbuhan penjualan tinggi maka perusahaan akan memiliki kenaikan pendapatan sehingga perusahaan akan memiliki kas yang lebih banyak dari hasil pendapatan tersebut. Oleh karena itu, dirumuskan hipotesis penelitian sebagai berikut:

H7: Sales growth berpengaruh positif terhadap cash holding.

Anjum dan Malik (2013), Ali et al (2016) dan Jamil et al (2016) menemukan hubungan positif antara ukuran perusahaan dengan cash holding. Peningkatan ukuran perusahaan menyebabkan saldo kas yang lebih tinggi karena perusahaan yang lebih besar cenderung mempunyai kebutuhan dan kewajiban yang lebih besar daripada perusahaan kecil. Basheer (2014) menemukan hasil yang berbeda antara ukuran perusahaan dan cash holding. Skala ekonomi dalam manajemen kas memungkinkan perusahaan besar untuk memperoleh pendanaan dengan cara yang lebih mudah dan murah (Bigelli dan SánchezVidal, (2012). Kim et al. (2011) juga berpendapat bahwa biaya tetap yang berhubungan dengan peminjaman yang tidak sebanding dengan besarnya kredit, dan relatif lebih rumit untuk perusahaan kecil. Oleh karena itu, diperkirakan bahwa perusahaan yang lebih besar akan menyimpan kas yang lebih sedikit karena mereka berasumsi bahwa mereka akan dengan mudah mendapat pinjaman sehingga mereka tidak perlu memegang kas lebih banyak. Dengan uraian tersebut, maka dirumuskan hipotesis penelitian sebagai berikut:

H8: Firm size berpengaruh negatif terhadap cash holding.

\section{METODE}

Sampel. Sampel diperoleh menggunakan metode purpose sampling. Sampel yang diambil memenuhi kriteria, yaitu: (1) Perusahaan non finansial; (2) Terdaftar di Bursa Efek Indonesia (BEI) dalam periode penelitian yaitu 2012, 2013, 2014 dan 2015 berturut-turut. Didapat 328 sampel perusahaan yang sesuai dengan kriteria tersebut (1312 observasi). 
Jenis dan Sumber Data. Jenis data yang digunakan dalam penelitian ini adalah data sekunder berupa laporan keuangan tahunan perusahaan yang terdaftar BEI tahun 20122015 yang diperoleh dari www.idx.co.id dan data yang diperoleh dari Indonesia Capital Market Directory (ICMD).

Operasionalisasi Variabel Penelitian. Variabel dependen. Cash holding adalah jumlah kepemilikan kas yang dimiliki oleh perusahaan. Dalam penelitian ini, cash holding menjadi variabel terikat (Y). Cash holding adalah rasio keuangan yang membandingkan jumlah kas dan setara kas perusahaan dengan jumlah aktiva perusahaan (Marfuah dan Zulhilmi, 2015). Cash Holding dapat dihitung dengan rumus sebagai berikut:

Cash Holding $=\frac{\text { Kas }+ \text { setara kas }}{\text { Total aset }}$

\section{Variabel Independen}

a) Cash Flow. Cash Flow adalah suatu laporan yang menyajikan informasi tentang arus kas masuk dan arus kas keluar suatu perusahaan pada periode waktu tertentu. Menurut Basheer (2014), literatur keuangan mendefinisikan kas sebagai jumlah dari laba sebelum pajak dengan penyusutan (Ferreira dan Vilela, 2004; Ozkan dan Ozkan 2004).

$$
\text { Cash Flow }=\frac{\text { profit beforetax }+ \text { depreciation }}{\text { Total asset }}
$$

b) Cash Flow Variability

Cash flow variability adalah suatu rasio standar deviasi dari arus kas terhadap nilai rata-rata dari total aset yang dimiliki perusahaan (Kariuki, 2015).

$$
\begin{aligned}
& \text { Cush Flow Vur iubility } \\
& \qquad=\frac{\sigma(\text { profit hefore tax of the previous } 3 \text { years })+\text { Depreciation }}{\text { Total asset of } 3 \text { years period }}
\end{aligned}
$$

c) Cash Conversion Cycle (CCC). CCC adalah berapa lama dana terikat dalam modal kerja, atau berapa lama waktu antara pembayaran untuk modal kerja dan penagihan kas dari penjualan modal kerja tersebut. Perhitungan CCC meliputi berapa lama waktu yang diperlukan untuk menjual inventory perusahaan, berapa lama waktu yang diperlukan untuk menagih hutang dan berapa lama waktu yang dimiliki perusahaan untuk membayar hutangnya (Marfuah dan Zulhilmi, 2015).

CCC diukur dengan rumus:

$$
\text { CCC }=\text { Days of Inventory }+ \text { Days of Receivable }- \text { Days of Payable }
$$

Dimana:

$$
\begin{aligned}
& \text { Days of Inventory }=\frac{\text { Inventory }}{H P P / 365} \\
& \text { Days of Receivable }=\frac{\text { Account Receivable }}{\text { Penjualan } / 365}
\end{aligned}
$$




$$
\text { Days of Payable }=\frac{\text { Account Payable }}{\frac{H P P}{365}}
$$

d) Liquidity. Likuiditas adalah kemampuan perusahaan dalam memenuhi kewajiban jangka pendeknya. Dalam penelitian ini untuk mengukur likuiditas digunakan current ratio yang digunakan untuk mengukur kemampuan perusahaan dalam memenuhi kewajiban jangka pendeknya menggunakan aktiva lancar yang dimiliki. Current ratio dapat dihitung dengan rumus sebagai berikut:

$$
\text { Current ratio }=\frac{\text { Current Asset }}{\text { Current Liabilities }}
$$

e) Leverage. Leverage merupakan rasio keuangan perusahaan yang membandingkan antara total utang dengan total aset perusahaan (Marfuah dan Zulhilmi, 2015). Leverage dapat dihitung dengan rumus sebagai berikut:

$$
\text { Leverage }=\frac{\text { Total Liabilities }}{\text { Total Asset }}
$$

f) Net Working Capital (NWC). Net working capital merupakan selisih antara aset lancar dengan kewajiban lancar dibagi dengan total aset. Rumus dari net working capital adalah sebagai berikut (Kafayat et al., 2014):

$$
\text { Net Working Capital }=\frac{\text { Current Asset }- \text { Current Liabilities }}{\text { Total Asset }}
$$

g) Sales Growth. Sales growth adalah peningkatan penjualan selama periode waktu tertentu, hal ini seringkali terjadi pada perusahaan tetapi belum tentu terjadi setiap tahunnya (Marfuah dan Zulhilmi, 2015).

$$
\text { Growth Opportunity }=\frac{\text { Total sales tahun }_{t}-\text { Total sales tahun }_{t-1}}{\text { Total sales } \text { tahun }_{t-1}} \times 100 \%
$$

h) Firm Size. Ukuran perusahaan adalah ukuran atau besarnya asset yang dimiliki oleh perusahaan. In merupakan natural logaritma dari total aset (Kariuki, 2015).

Firm size $=\ln ($ total aset $)$

\section{HASIL DAN PEMBAHASAN}

Analisis Deskriptif. Deskripsi data dari seluruh variabel peneltian yang meliputi nilai minimum, maksimum, rata-rata, dan standar deviasi, disajikan pada Tabel 1.

Rata-rata nilai cash holding perusahaan sebesar 0,0980 dan standar deviasi 0,1069 dengan nilai minimum dan maksimum masing-masing adalah 0,0001 dan 0,8007. Data ini mengindikasikan bahwa jumlah kas dan setara kas yang dipegang oleh perusahaan secara rata-rata sangat kecil, yaitu kurang dari 10\% dari keseluruhan aset yang dimiliki oleh perusahaan dengan variasi yang sangat besar antar perusahaan.

Nilai minimum dan maksimum untuk cash flow adalah $-0,3908$ dan 0,9782. Nilai rata-ratanya adalah 0,1309 dengan standar deviasi sebesar 0,1624. Nilai tersebut mengindikasikan bahwa tingkat arus kas perusahaan non finansial cenderung kecil bahkan 
ada yang memiliki nilai negatif yang mengindikasikan laba sebelum pajak yang negatif juga dengan variasi data yang cukup tinggi antar perusahaan.

Tabel 1. Statistik Deskriptif

\begin{tabular}{lccccc}
\hline & Obs & Minimum & Maximum & Mean & Std. Deviation \\
CASHHOLD & 1312 & 0,0001 & 0,8007 & 0,0980 & 0,1069 \\
CF & 1312 & $-0,3908$ & 0,9782 & 0,1309 & 0,1624 \\
CFV & 1312 & 0,0002 & 0,3469 & 0,0390 & 0,0508 \\
CCC (hari) & 1312 & $-1.768,9025$ & $12.783,8969$ & 229,7688 & 749,0803 \\
LIQ & 1312 & 0,1013 & 32,6616 & 2,1756 & 2,5385 \\
LEV & 1312 & 0,0003 & 0,9846 & 0,4692 & 0,2090 \\
NWC & 1312 & $-3,6519$ & 1,9912 & 0,1643 & 0,2894 \\
SG & 1312 & $-0,8712$ & 9,8630 & 0,1613 & 0,5531 \\
SIZE (jutaan & 1312 & & & & \\
Rp) & & 16.821 & 245.435 .000 & 7.356 .406 & 16.838 .048 \\
\end{tabular}

Sumber: data diolah oleh peneliti

Rata-rata nilai cash flow variability perusahaan sebesar 0,0390 dan standar deviasi 0,0508 dengan nilai minimum dan maksimum masing-masing adalah 0,0002 dan 0,3469. Data ini mengindikasikan bahwa rata-rata tingkat variabilitas arus kas antar perusahan cukup rendah dengan nilai variasi data yang cukup tinggi.

Nilai minimum dan maksimum cash conversion cycle masing-masing sebesar $-1.768,9025$ dan $12.783,8969$. Nilai rata-ratanya adalah sebesar 229,7688 dengan standar deviasi sebesar 749,0803. Hal ini mengindikasikan bahwa rata-rata waktu yang diperlukan dalam proses pembelian persediaan oleh perusahaan kepada supplier, proses penagihan piutang oleh perusahaan kepada pembeli dan proses pelunasan utang oleh perusahaan kepada supplier sangat lama, yaitu hampir 230 hari. Bahkan ada perusahaan yang mempunyai nilai cash conversion cycle negatif yang berarti perusahaan tersebut mempunyai rata-rata waktu yang diperlukan dalam proses pelunasan utang oleh perusahaan kepada supplier melebihi waktu yang diperlukan dalam proses pembelian persediaan oleh perusahaan kepada supplier dan proses penagihan piutang oleh perusahaan kepada pembeli. Variasi data cash conversion cycle ini antar perusahaan juga sangat besar.

Rata-rata nilai liquidity perusahaan sebesar 2,1756 dan standar deviasi 2,5385 dengan nilai minimum dan maksimum masing-masing adalah 0,1013 dan 32,6616. Data ini mengindikasikan bahwa rata-rata perusahaan memiliki aktiva lancar yang cukup untuk melunasi kewajiban lancarnya dengan nilai variasi yang cukup tinggi antar perusahaan

Nilai minimum dan maksimum untuk leverage adalah 0,0003 dan 0,9846. Nilai rataratanya adalah 0,4692 dengan standar deviasi sebesar 0,2090. Nilai tersebut mengindikasikan bahwa rata-rata aset perusahaan yang dibiayai oleh utang cenderung rendah, yaitu tidak lebih dari 50\% dengan nilai variasi yang cukup rendah juga.

Rata-rata nilai net working capital perusahaan sebesar 0,1643 dan standar deviasi 0,2894 dengan nilai minimum dan maksimum masing-masing adalah -3,6519 dan 1,9912. Data ini mengindikasikan bahwa rata-rata tingkat modal kerja bersih yang dimiliki perusahaan sangat rendah bahkan terdapat perusahaan yang memiliki modal kerja bersih yang negatif sedangkan nilai variasi datanya cenderung tinggi.

Nilai minimum dan maksimum untuk sales growth adalah $-0,8712$ dan 9,8630. Nilai rata-ratanya adalah 0,1613 dengan standar deviasi sebesar 0,5531. Nilai tersebut 
mengindikasikan bahwa tingkat pertumbuhan penjualan perusahaan cenderung rendah bahkan terdapat nilai negatif yang artinya perusahaan justru mengalami penurunan nilai penjualan. Sedangkan nilai variasinya cukup tinggi.

Rata-rata nilai firm size perusahaan yang dilihat dari total asetnya adalah sebesar Rp 7.356.406 (dalam jutaan) dan standar deviasi Rp 16.838.048 (dalam jutaan) dengan nilai minimum dan maksimum masing-masing adalah $\mathrm{Rp} 16.821$ (dalam jutaan) dan Rp 245.435.000 (dalam jutaan). Data ini mengindikasikan bahwa rata-rata perusahan memiliki ukuran perusahaan yang cukup rendah dengan nilai variasi data yang cukup tinggi.

Uji Multikolinearitas. Tabel 2 menunjukkan tidak ada nilai korelasi yang lebih besar dari 0,8 sehingga dapat dikatakan bahwa nilai korelasi antar variabel rendah.

Tabel 2. Hasil Uji Pearson Correlation

\begin{tabular}{|c|c|c|c|c|c|c|c|c|}
\hline & CF & CFV & CCC & LIQ & LEV & NWC & SG & SIZE \\
\hline CF & 1 & 0,7430 & $-0,0771$ & 0,0650 & $-0,1013$ & 0,2176 & 0,0355 & $-0,0675$ \\
\hline CFV & 0,7430 & 1 & $-0,0580$ & $\begin{array}{c}-8,06 \mathrm{E}- \\
05\end{array}$ & 0,0416 & $-0,0315$ & $-0,0252$ & $-0,1381$ \\
\hline CCC & $-0,0771$ & $-0,0580$ & 1 & 0,4239 & $-0,2109$ & $-0,0031$ & $-0,0297$ & $-0,0435$ \\
\hline & & $-8,06 \mathrm{E}-$ & & & & & & \\
LIQ & 0,0650 & 05 & 0,4239 & 1 & $-0,4942$ & 0,5945 & 0,0299 & $-0,1298$ \\
\hline LEV & $-0,1013$ & 0,0416 & $-0,2109$ & $-0,4942$ & 1 & $-0,3539$ & $-0,0191$ & 0,1598 \\
\hline NWC & 0,2176 & $-0,0315$ & $-0,0031$ & 0,5945 & $-0,3539$ & 1 & 0,0431 & $-0,0841$ \\
\hline SG & 0,0355 & $-0,0252$ & $-0,0297$ & 0,0299 & $-0,0191$ & 0,0431 & 1 & 0,0114 \\
\hline SIZE & $-0,0675$ & $-0,1381$ & $-0,0435$ & $-0,1298$ & 0,1598 & $-0,0841$ & 0,0113 & 1 \\
\hline
\end{tabular}

Sumber: data diolah oleh peneliti

Pembahasan. Hasil pengujian hipotesis dengan menggunakan hasil regresi data panel fixed effect model ditunjukkan pada Tabel 3.

Tabel 3. Hasil Regresi Data Panel Fixed Effect Model

Dependent Variable: CASHHOLD

Method: Panel Least Squares

Date: 09/17/16 Time: 17:36

Sample: 20122015

Periods included: 4

Cross-sections included: 328

Total panel (balanced) observations: 1312

\begin{tabular}{crrrr}
\hline \hline Variable & Coefficient & Std. Error & t-Statistic & Prob. \\
\hline \hline CF & $-0,0061$ & 0,1258 & $-0,0487$ & 0,9611 \\
CFV & $-0,6353$ & 0,3905 & $-1,6265$ & 0,1042 \\
CCC & $-2,80 \mathrm{E}-05$ & $2,19 \mathrm{E}-05$ & $-1,2788$ & 0,2013 \\
LIQ & $-0,0009$ & 0,0084 & $-0,1121$ & 0,9108 \\
LEV & $-0,1608$ & 0,1140 & $-1,4111$ & 0,1585 \\
NWC & 0,2714 & 0,0751 & 3,6107 & 0,0003 \\
SG & 0,0360 & 0,0168 & 2,1340 & 0,0331 \\
SIZE & $-0,2595$ & 0,0624 & $-4,1577$ & 0,0000 \\
C & 0,4182 & 0,4010 & 1,0430 & 0,2972 \\
\hline \hline
\end{tabular}


Effects Specification

\begin{tabular}{lrlr}
\hline Cross-section fixed (dummy variables) & \\
\hline \hline R-squared & 0.819426 & Mean dependent var & -1.286484 \\
Adjusted R-squared & 0.757446 & S.D. dependent var & 0.571888 \\
S.E. of regression & 0.281653 & Akaike info criterion & 0.520069 \\
Sum squared resid & 77.42465 & Schwarz criterion & 1.846478 \\
Log likelihood & -5.165579 & Hannan-Quinn criter. & 1.017515 \\
F-statistic & 13.22086 & Durbin-Watson stat & 2.187368 \\
Prob(F-statistic) & 0.000000 & & \\
\hline
\end{tabular}

Sumber: data diolah oleh peneliti

Pengaruh Cash Flow terhadap Cash Holding. Variabel cash flow menunjukkan koefisien negatif sebesar $-0,0061$ dengan probabilitas sebesar 0,9611. Hal ini mengindikasikan bahwa cash flow berpengaruh negatif tidak signifikan terhadap cash holding. Oleh karena itu, hipotesis 1 yang menyatakan bahwa cash flow berpengaruh negatif terhadap cash holding ditolak. Hasil ini sejalan dengan Jinkar (2013) yang menyatakan bahwa tidak terdapat hubungan yang signifikan antara cash flow dan cash holding.

Pengaruh Cash Flow Variability terhadap Cash Holding. Variabel cash flow variability menunjukkan koefisien negatif sebesar -0,6353 dengan probabilitas sebesar 0,1042. Hal ini mengindikasikan bahwa cash flow variability berpengaruh negatif tidak signifikan terhadap cash holding. Oleh karena itu, hipotesis 2 yang menyatakan bahwa cash flow variability berpengaruh positif terhadap cash holding ditolak. Hasil ini sejalan dengan penelitian Dalbor dan Oak (2011) yang menyatakan bahwa tidak terdapat hubungan yang signifikan antara cash holding dan variability of cash flow.

Pengaruh Cash Conversion Cycle terhadap Cash Holding. Variabel cash conversion cycle menunjukkan koefisien negatif sebesar -2,80E-05 dengan probabilitas sebesar 0,2013 . Hal ini mengindikasikan bahwa cash conversion cycle berpengaruh negatif tidak signifikan terhadap cash holding. Oleh karena itu, hipotesis 3 yang menyatakan bahwa cash conversion cycle berpengaruh negatif terhadap cash holding ditolak. Hasil ini tidak mendukung Bigelli dan Vidal (2012) yang menyatakan bahwa cash conversion cycle berpengaruh signifikan terhadap cash holding perusahaan.

Pengaruh Liquidity terhadap Cash Holding. Variabel liquidity menunjukkan koefisien negatif sebesar -0,0009 dengan probabilitas sebesar 0,9108. Hal ini mengindikasikan bahwa liquidity berpengaruh negatif tidak signifikan terhadap cash holding. Oleh karena itu, hipotesis 4 yang menyatakan bahwa liquidity berpengaruh negatif terhadap cash holding ditolak. Hasil ini sejalan dengan Chen dan Liu (2013) yang menyatakan bahwa dia tidak menemukan bukti yang mendukung bahwa likuiditas adalah aspek yang penting bagi perusahaan dalam menentukan tingkat keputusan cash holding.

Pengaruh Leverage terhadap Cash Holding. Variabel leverage menunjukkan koefisien negatif sebesar $-0,1608$ dengan probabilitas sebesar 0,1585 . Hal ini mengindikasikan bahwa leverage berpengaruh negatif tidak signifikan terhadap cash holding. Oleh karena itu, hipotesis yang menyatakan bahwa leverage berpengaruh negatif terhadap cash holding 
ditolak. Hasil ini mendukung Jamil et al (2016). Akan tetapi, hasil ini tidak mendukung temuan Basheer (2014) dan Marfuah dan Zulhilmi (2015) yang menyatakan bahwa leverage memiliki pengaruh yang signifikan terhadap corporate cash holding.

Pengaruh Net Working Capital terhadap Cash Holding. Variabel net working capital menunjukkan koefisien positif sebesar 0,2714 dengan probabilitas sebesar 0,0003. Hal ini mengindikasikan bahwa net working capital berpengaruh positif signifikan terhadap cash holding. Oleh karena itu, hipotesis 6 yang menyatakan bahwa net working capital berpengaruh negatif terhadap cash holding ditolak. Peningkatan modal kerja bersih mengarah ke saldo kas yang lebih tinggi karena perusahaan yang sangat likuid cenderung memiliki saldo kas yang lebih tinggi begitupun sebaliknya dengan perusahaaan dengan likuiditas yang lebih rendah (Anjum dan Malik, 2013). Hasil ini sejalan dengan Jamil et al (2016) dan Anjum dan Malik (2013) yang menemukan hubungan positif antara net working capital dan cash holding.

Pengaruh Sales Growth terhadap Cash Holding. Variabel sales growth menunjukkan koefisien positif sebesar 0,0360 dengan probabilitas sebesar 0,0331. Hal ini mengindikasikan bahwa sales growth berpengaruh positif signifikan terhadap cash holding. Oleh karena itu, hipotesis 7 yang menyatakan bahwa sales growth berpengaruh positif terhadap cash holding diterima. Ketika pertumbuhan penjualan tinggi maka perusahaan akan memiliki kenaikan pendapatan sehingga perusahaan akan memiliki kas yang lebih banyak dari hasil pendapatan tersebut. Hasil ini sejalan dengan Akguc dan Choi, (2013) dan Bates et al., (2009) yang menemukan hubungan positif antara sales growth dan cash holding.

Pengaruh Firm Size terhadap Cash Holding. Variabel firm size menunjukkan koefisien negatif sebesar -0,2595 dengan probabilitas sebesar 0,0000. Hal ini mengindikasikan bahwa firm size berpengaruh negatif signifikan terhadap cash holding. Oleh karena itu, hipotesis yang menyatakan bahwa firm size berpengaruh negatif terhadap cash holding diterima. Perusahaan yang lebih besar akan menyimpan kas yang lebih sedikit karena mereka berasumsi bahwa mereka akan dengan mudah mendapat pinjaman sehingga mereka tidak perlu memegang kas lebih banyak. Hasil ini sejalan dengan Bigelli dan Sánchez-Vidal, (2012) dan Kim et al. (2011) yang menemukan hubungan negatif antara firm size dan cash holding. Akan tetapi, hasil diatas tidak mendukung Ali et al (2016) yang mengatakan ukuran perusahaan berpengaruh positif signifikan terhadap cash holdings.

\section{PENUTUP}

Simpulan. Penelitian ini bertujuan untuk mengetahui faktor-faktor yang mempengaruhi cash holdings perusahaan di Bursa Efek Indonesia. Hasil penelitian ini menyimpulkan bahwa faktor-faktor utama yang mempengaruhi corporate cash holding pada perusahaan non finansial yang terdaftar di BEI periode 2012-2015 adalah net working capital (positif), sales growth (positif), dan firm size (negatif). Akan tetapi variabel cash flow, cash flow variability, cash conversion cycle, liquidity, dan leverage tidak memiliki pengaruh yang signifikan terhadap corporate cash holdings.

Saran. Saran-saran yang dapat diberikan untuk penelitian selanjutnya adalah sebagai berikut: (1) Menggunakan proksi lain untuk mengukur variabel cash flow variability 
misalnya ratio of standard deviation of cash flows to average total asset, liquidity misalnya quick ratio, dan leverage misalnya dengan total debt to equity ratio; (2) Memperluas sampel penelitian dengan menambah jumlah periode penelitian; (3) Menambahkan variabel-variabel lain yang diduga dapat mempengaruhi corporate cash holding seperti dividen, bank borrowing, corporate governance, dan market-to-book; (4) Menambah dummy sektor industri untuk melihat apakah ada perbedaan tingkat cash holdings pada setiap sektor industri di Bursa Efek Indonesia.

\section{DAFTAR PUSTAKA}

Akguc, Serkan dan Jongmoo Jay Choi. (2013) "Cash Holding in Private and Public Firms: Evidence from Europe". Proceedings, Academy of International Business Conference.

Al-Najjar, Basil. (2013) "The Financial Determinants of Corporate Cash Holdings: Evidence from some Emerging Markets", International Business Review, 22(1), 77 88.

Al-Najjar, B. dan Belghitar, Y. (2011) "Corporate Cash Holdings And Dividend Payments: Evidence From Simultaneous Analysis", Managerial and Decision Economics. 32, 231-41.

Al-Shubiri, Faris Nasif dan Nassem Mohammad Aburumman. (2013) "The Relationship between Cash Conversion Cycle and Financial Characteristic of Industrial Sectors: An Empirical Study", Investment Management and Financial Innovations. 10, 95102.

Ali, S., Mishkat Ullah dan Nazir Ullah. (2016) "Determinants of Corporate Cash Holdings Case of Textile Sector in Pakistan". International Journal of Economics \& Management Sciences, 5 (3), 1-10.

Anjum, Sara dan Qaisar Ali Malik. (2013) "Determinants of Corporate Liquidity: An Analysis of Cash Holdings". IOSR Journal of Business and Management. 7, 94-100.

Basheer, Muhammad Farhan. (2014) "Impact of Corporate Governance on Corporate Cash Holdings: An Empirical Study of Firms in Manufacturing Industry of Pakistan". International Journal of Innovation and Applied Studies. 7, 1371-1383.

Bates, T., Kahle, K. dan Stulz R.. (2009) "Why do U.S. Firms hold so much more Cash than they used to?". Journal of Finance. LXIV (5).

Bigelli, M. and Sánchez-Vidal, J. (2012) "Cash Holdings In Private Firms". Journal of Banking \& Finance. 36, 26-35.

Chen, Siheng dan Shuai Liu. (2013) "Corporate Cash Holdings: Study of Chinese Firms". Working paper, Simon Fraser University.

Chen, Y., Dou, P. Y., Rhee, S. G., Truong, C., Veeraraghavan, M. (2015) "National Culture And Corporate Cash Holdings Around The World". Journal of Banking \& Finance, 50, 1-18.

Dalbor, Michael dan Seonghee Oak. (2011) "An Examination of Cash Holding Policies in U.S. Casino Firms". Proceedings International CHRIE Conference-Refereed Track.

Dittmar, A., Mahrt-Smith, J., dan Servaes, H. (2003) "International Corporate Governance And Corporate Cash Holdings". Journal of Financial and Quantitative Analysis. Vol. 38(1), 111-133.

Faleye, Olubunmi. (2004) "Cash and Corporate Control”. Journal of Finance, 59 (5), 2041-2060 
Ferreira, M. dan A. Vilela. (2004) "Why Do Firms Hold Cash? Evidence from EMU Countries". European Financial Management, 10 (2), 295-319.

Jamil, S., Amna Anwar, Naila Afzaal, Adnan Tariq, dan Mohsin Asif. (2016) "Determinants of Corporate Cash Holdings: Empirical Analysis of Pakistani Firms". IOSR Journal of Economics and Finance, 7 (3), 29-35

Jensen, M. (1986) "Agency costs of free cash flow, corporate finance, and takeovers". American Economic Review, 76, 323-329.

Jinkar, Rebecca Theresia. (2013) "Analisa Faktor-faktor Penentu Kebijakan Cash Holding Perusahaan Manufaktur di Indonesia”. Mini Economica, Edisi 42, 129-146.

Kafayat, Atif, Khalil Ur Rehman, dan Farooq M. (2014) "Factors Affecting Corporate Cash Holding of Non-Financial Firms in Pakistan", Acta Universitatis Danubius (Economica). 10 (3). 35-43.

Kariuki, Samuel Nduati, Gregory S. Namusonge, dan George Orwa. (2015) "Determinants of Corporate Cash Holdings: Evidence from Private Manufacturing Firms in Kenya". International Journal of Advanced Research in Management and Social Sciences. 4, 15-33.

Kim, J., Kim, H., dan Woods, D. (2011) "Determinants Of Corporate Cash-Holding Levels: An Empirical Examination Of The Restaurant Industry". International Journal of Hospitality Management. 30 (3), 568-574.

Marfuah dan Ardan Zulhilmi. (2015) "Pengaruh Growth Opportunity, Net Working Capital, Cash Conversion Cycle, dan Leverage terhadap Cash Holding Perusahaan". Jurnal Ekonomi dan Bisnis Optimum. 5, 32-43.

Martínez-Sola, C., García-Teruel, P. J., dan Martínez-Solano, P. (2013) "Corporate cash holding and firm value", Applied Economics. 45, 161-170.

Myers, S. C, dan Majluf, N. S. (1984) "Corporate Financing and Investment Decisions When Firms Have Information That Investors Do Not Have". Journal of Financial Economics, 13(2), 187-221

Ogundipe Lawrencia Olatunde, Sunday Emmanuel Ogundipe, dan Samuel Kehinde Ajao. (2012). "Cash Holding and Firm Characterictics: Evidence From Nigerian Emerging Market", Journal of Business, Economic \& Finance. Vol. 1.

Opler, T., Pinkowitz, L., Stulz, R., dan Williamson, R. (1999) "The Determinants And Implications Of Corporate Cash Holdings". Journal of financial economics. 52 (1), 3 46.

Ozkan, A. and N. Ozkan. (2004) "Corporate Cash Holdings: An Empirical Investigation of UK Companies". Journal of Banking and Finance. 28, 2103-2134.

Uyar, Ali dan Cemil Kuzey. (2014) "Determinants of Corporate Cash Holdings: Evidence from Emerging Market of Turkey", Applied Economics, 46, 1035-1048.

Weidemann, J. F. (2016) "The Determinants of Cash Holdings: Evidence from MetaRegression Analysis". Proceedings EFMA 2016 Conference

William, dan Fauzi, Syarief. (2013) "Analisis Pengaruh Growth Opportunity, Net Working Capital, dan Cash Conversion Cycle Terhadap Cash Holdings Perusahaan Sektor Pertambangan". Jurnal Ekonomi dan Keuangan, 1 (2). 